
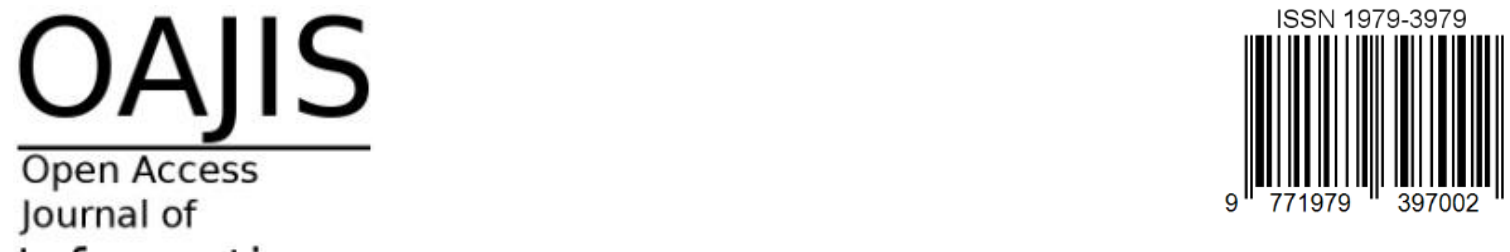

Information

Systems

is.its.ac.id/pubs/oajis/

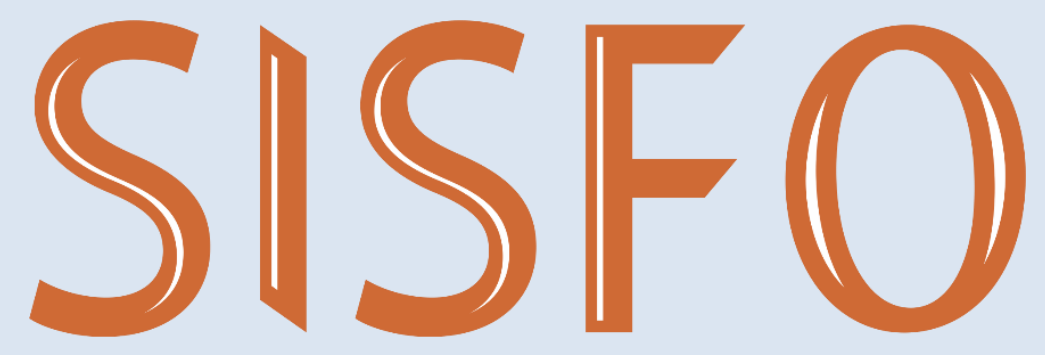

Inspirasi Profesional Sistem Informasi

\section{People}

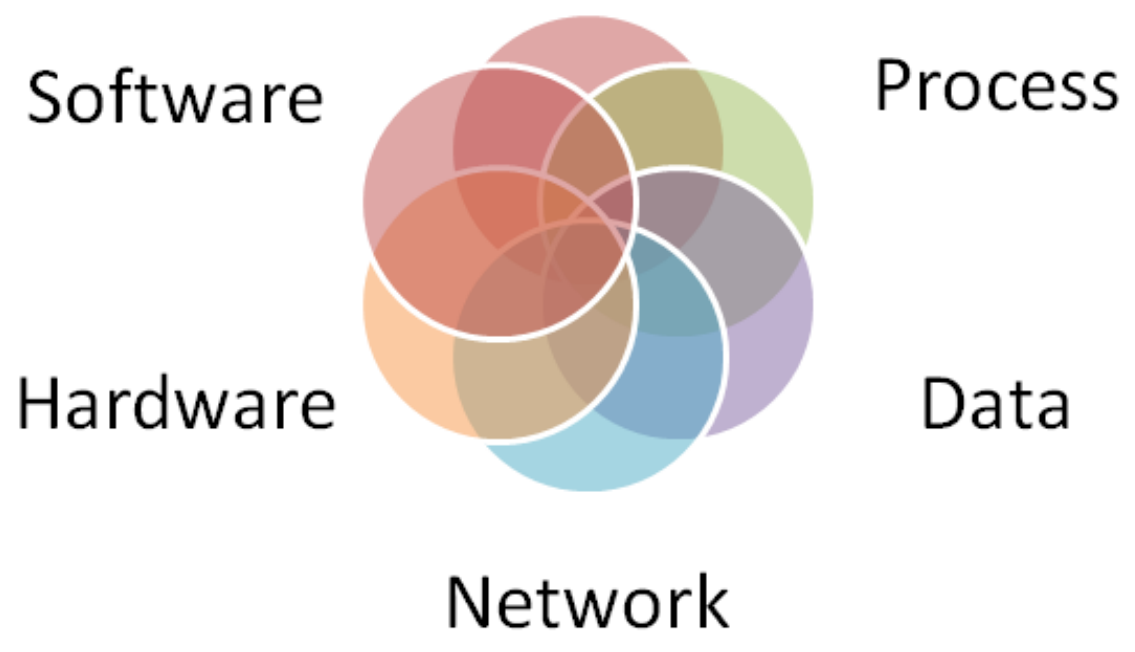


OAJIS

Journal of

Information

Systems

is.its.ac.id/pubs/oajis/

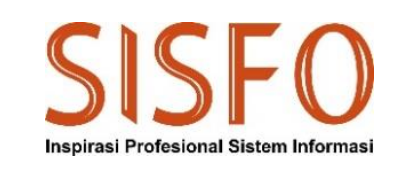

Jurnal Sisfo Vol. 09 No. 01 (2019) i-ii

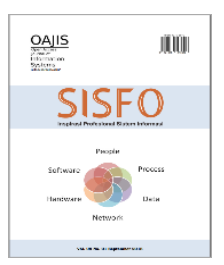

\section{Pimpinan Redaksi}

Faizal Mahananto

\section{Dewan Redaksi}

Eko Wahyu Tyas Darmaningrat

Amna Shifia Nisafani

Arif Wibisono

Rully Agus Hendrawan

\section{Tata Pelaksana Usaha}

Achmad Syaiful Susanto

Rini Ekowati

\section{Sekretariat}

Departemen Sistem Informasi - Fakultas Teknologi Informasi dan Komunikasi

Institut Teknologi Sepuluh Nopember (ITS) - Surabaya

Telp. 031-5999944 Fax. 031-5964965

Email: editor@jurnalsisfo.org

Website: http://jurnalsisfo.org

Jurnal SISFO juga dipublikasikan di Open Access Journal of Information Systems (OAJIS)

Website: http://is.its.ac.id/pubs/oajis/index.php 
OAJIS Journal of Information

Systems

is.its.ac.id/pubs/oajis/

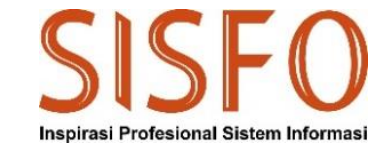

Jurnal Sisfo Vol. 09 No. 01 (2019) i-ii

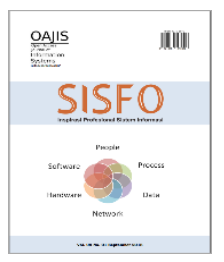

\section{Mitra Bestari}

A'ang Subiyakto, S.Kom., M.Kom., Ph.D. (UIN Syarif Hidayatullah Jakarta)

Alvin Sahroni, S.T., M.Eng., Ph.D. (Universitas Islam Indonesia)

Leon Andretti Abdillah, S.Kom., M.M. (Universitas Bina Darma)

Nur Aini Rakhmawati, S.Kom., M.Sc.Eng., Ph.D. (Institut Teknologi Sepuluh Nopember)

Renny Sari Dewi, S.Kom., M.Kom. (Universitas Internasional Semen Indonesia)

Reny Nadlifatin, S.Kom., M.BA., Ph.D. (Institut Teknologi Sepuluh Nopember)

Retno Aulia Vinarti, S.Kom., M.Kom., Ph.D. (Institut Teknologi Sepuluh Nopember)

Rradityo Prasetianto Wibowo, S.Kom., M.Kom. (Institut Teknologi Sepuluh Nopember)

Satria Fadil Persada, S.Kom., M.BA., Ph.D. (Institut Teknologi Sepuluh Nopember)

Sholiq, S.T., M.Kom. (Institut Teknologi Sepuluh Nopember)

Yogantara Setya Dharmawan, S.Kom., MBusProcessMgt (Universitas Internasional Semen Indonesia) 


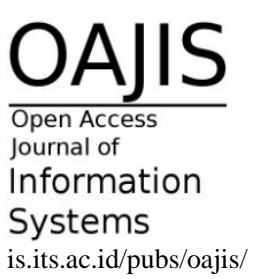

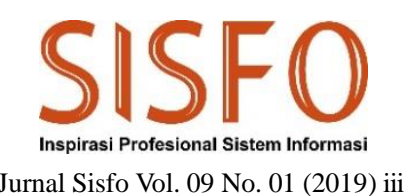

Jurnal Sisfo Vol. 09 No. 01 (2019) iii

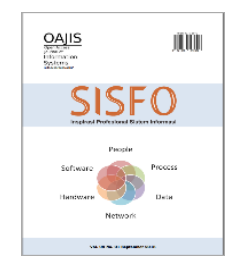

\section{Daftar Isi}

Perencanaan Strategi SI/TI Menggunakan Metode Ward and Peppard di BARENLITBANGDA Kabupaten Semarang

Dedy, Prihanto Ngesti Basuki, Hanna Prillysca Chernovita

Penggunaan Algoritma C4.5 untuk Rekomendasi Peminjaman Uang pada Koperasi Sejahtera Mandiri

Muhammad Imam Tegar, Wachyu Hari Haji.....

Analysis of Purchase Intention using Mobile Shopping Application for Generation X and Y in Indonesia

Mudjahidin, Andre Parvian Aristio, Al Lilah Nur Hasanah.

Analisis Struktur Service Desk di Perguruan Tinggi (Studi Kasus: Institut Teknologi Sepuluh Nopember Surabaya)

Anisah Herdiyanti, Mona Syahmi, Tony Dwi Susanto

Analisis Intensi Perilaku Untuk Mengadopsi dan Merekomendasikan Aplikasi Mobile Payment dengan Metode Structural Equation Modelling

Andre Parvian Aristio, Mudjahidin, Nasywa Ibtisamah. 51 
Halaman ini sengaja dikosongkan 


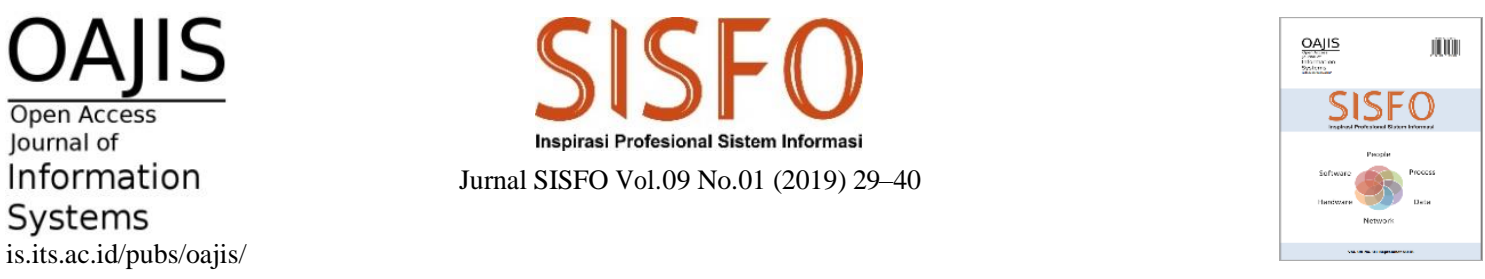

\title{
Purchase Intention Analysis of Mobile Shopping Application for Generation X and Y
}

\author{
Mudjahidin*, Andre Parvian Aristio, Al Lilah Nur Hasanah \\ Information Systems Department, Faculty of Information and Communication Technology, Institut Teknologi Sepuluh Nopember
}

\begin{abstract}
In this study, we present the analysis of purchase intention on the use of mobile shopping applications for $\mathrm{X}$ and $\mathrm{Y}$ generations aged 15-34 years in Indonesia, in particular for Tokopedia, Bukalapak, and Shopee. Based on the results of the discussion with members of the Enterprise System Laboratory, we use the research model (by Gao et al.) to do this analysis. Initially, we explore in detail the research model into the SEM model. Subsequently, we implemented the SEM model by rearranging the questionnaire based on variables and hypotheses in the model. After testing the questionnaire, we surveyed customers who use the application. The results of this study are that purchase intention affected by satisfaction, flow, and trust (respectively, $\beta=0.74,0.72$, and 0.72). Moreover, based on the literature review, we propose regular usage, model subjective norms, and control variables (such as gender, age, and income).
\end{abstract}

Keywords: Purchase Intention, Mobile Shopping Applications, Satisfaction, Trust

(c) 2019 Jurnal SISFO.

Histori Artikel: Disubmit 18-09-2019; Direvisi 28-09-2019; Diterima 29-09-2018; Tersedia online 30-09-2019

\section{Introduction}

Currently, an online shopping company is in high demand by the people of Indonesia. Online shopping requires a mobile shopping application (MSA) to provide services following the wishes of the consumers $[1,2]$. For this reason, an online shopping company needs MSA that used in interacting with customers [3, $4,5]$. MSA has two main characteristics that are mobility and broad reach. By the features, customers can make a transaction in real-time, at any time, as well as get offers from many suppliers $[6,7]$.

Based on Google Play Data [8], currently the number of customers of MSA (in particular for Tokopedia, Bukalapak, and Shopee) are more than 70 million customers. Moreover, this

\# number is dominated by generation $X$ and $Y$, who have income and aged between 15 to 34 years. Therefore, to retain these $\mathrm{X}$ and $\mathrm{Y}$ generation, three online shopping company as the MSA provider, should make an effort to make their customers continued intention toward a purchase by the MSA. According to Anderson

*Corresponding Author

Email address: mudjahidin@is.its.ac.id (Mudjahidin)

https://doi.org/10.24089/j.sisfo.2019.09.003 
\& Srinivasan [9], retaining customers is a difficult challenge because there are more and more competitors. Retaining customers can prevent them from moving to other MSAs. Based on this explanation, an analysis of the factors that influence a customer's desire to make sustainable purchases using MSA is needed. Furthermore, recommendations are required to improve MSA based on the results of the analysis of factors that influence the purchase intention.

This article presents the purchase intention on the use of MSA for X and Y generations aged 15-34 years in Indonesia with structural equation modeling (SEM). For this reason, we held discussions with members in the Enterprise Systems Laboratory, Information Systems Department ITS (consisting of senior lecturers, and 25 undergraduate and graduate students) to determine the right model so that it can be used to perform the analysis. Furthermore, we also conducted a survey by distributing questionnaires that have been validated by experienced MSA (customers of Tokopedia, Shopee, and Bukalapak). The survey is carried out online through social media and chat/messaging applications. In this study, a literature study carried out to be able to add suggestions about variables that can be added in further research and compare the results of research with other studies to add insight and knowledge related to the effects of research with others.

The remainder of the article is structured as follows. First, we present the related work in Section 2. In section 3, we declare methodology. In Section 4, we describe results and discussion. Finally, in Section 5, we give a conclusion about this study.

\section{Related Work}

In this section, we explain the results of the literature review related to intention analysis. The articles reviewed from the reputable journals from 2010 to 2019 and presented below.

Delone and McLean [10] studied the quality of application system with the IS success model by compare and report the success or effectiveness of information systems. Followed by Utami [11] implemented this model in the case study of ITS SIAKAD by adopting system quality, information quality, service quality, user satisfaction, use, and net benefits, which used as assessment variables. Gao et al. [12] identified the factors that influence consumer intentions in online shopping conducted in China - followed by Dew et al. [5], which implemented this article to identify and built user trust online shopping through B2B emarketplaces through trust transfers. Kassim and Abdullah [13] studied the relationship between perceived service quality, satisfaction, trust, and loyalty in e-commerce settings with two different countries' cultures, namely Malaysia and Qatari. Next, this study implemented by Rohwiyati and Praptiestrini [14] in the Shopee case study. Chu and Zhang surveyed the relationship between customer trust, satisfaction, and purchase intention, which implemented in Tokopedia and Bukalapak [15, 16]. Lai and Chen [17] studied the influence of service quality, perceived value, satisfaction, and involvement on behavioral public transport passenger intentions implemented by Wahyuni [18] in the Trans Jakarta Bus Way. Next, we discuss these articles to choose the right model for analyzing purchase intention on the use of MSA for X and Y generations in Indonesia.

Finally, based on the results of the discussions, we choose the research model from Gao et al. [12] used for the analysis on purchase Intention of MSA for Generation X and Y in Indonesia.

\section{Methodology}

In the methodology, we describe the research model used in this study. First, we explore in detail the research model by Gao et al. [12] into the SEM model. Next, we present the mathematical equations formed by the model. Second, we implemented the SEM model by rearranging the questionnaire based on variables and hypotheses in the model. After testing the questionnaire, we surveyed customers of Tokopedia, Shopee, and 
Bukalapak by the requirements determined in this study, namely the customer experience which limited to $\mathrm{X}$ and $\mathrm{Y}$ generation in Indonesia.

\subsection{SEM Model}

Research model of Gao et al. [12] is a SEM model that consists of four exogenous variables (system quality, information quality, service quality, as well as privacy and security concern). Each variable affect trust, flow, and satisfaction (all three are endogenous variables). At the end of this model, all endogenous variables affect continued intention towards purchase. To implement this research model to the problem, we describe it into SEM model, which shows the relationship between exogenous and endogenous variables that affect purchase intention using MSA (i.e., continued intention towards mobile purchase) as shown in Fig. 1.

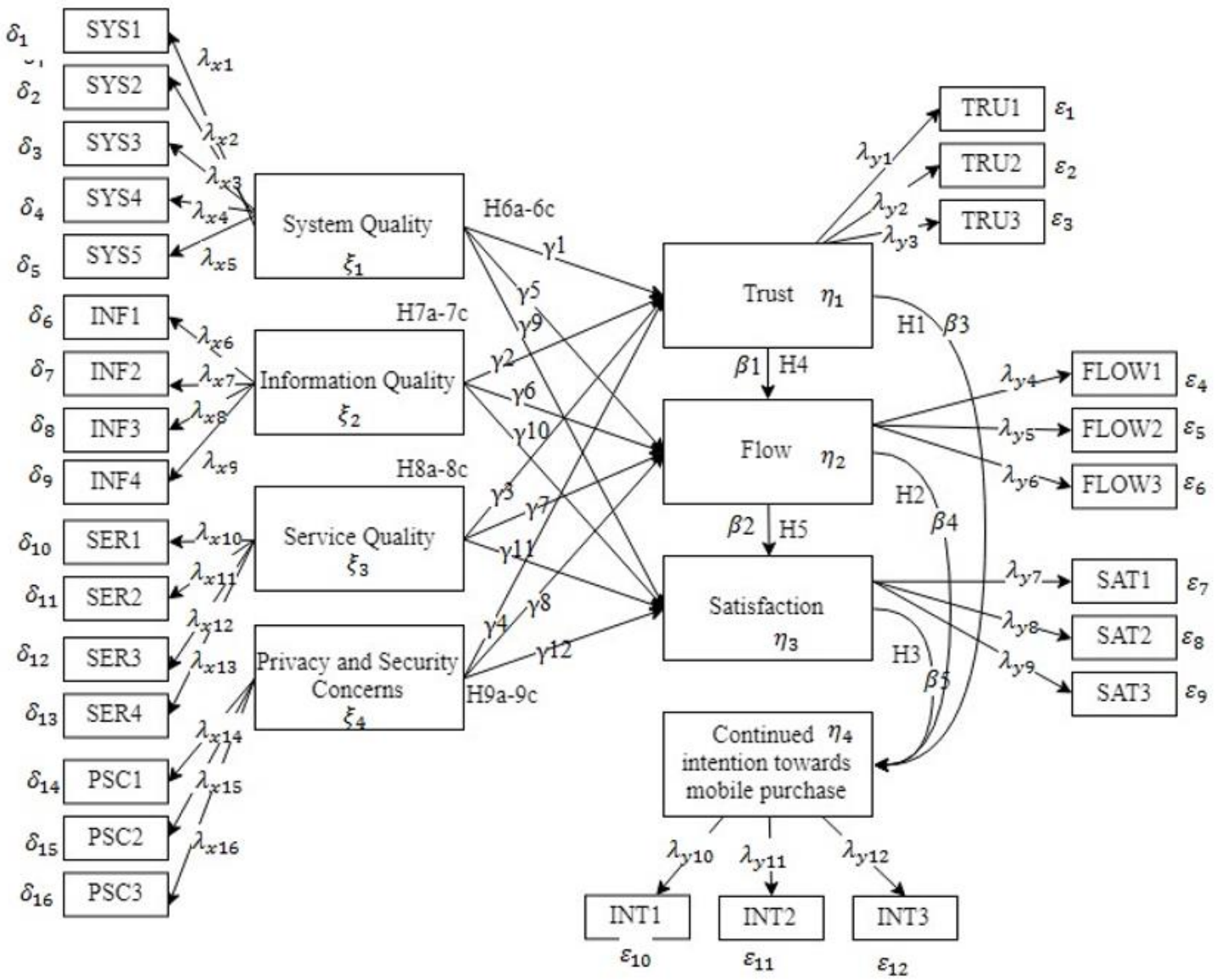

Figure 1. SEM model detailed for analysis purchase intention using MSA

Based on the SEM model above, we find the latent exogenous, i.e., $\lambda_{x 1}$ to $\lambda_{x 16}$ (SYS1 to 5, IF1 to 4, SER1 to 4 , and PSC1 to 3 ) as the constant of exogenous variables, $\xi_{1}$ to $\xi_{4}$ (System Quality, Information Quality, Service Quality, and Privacy and Security Concern) as the latent exogenous variables, and $\delta_{1}$ to $\delta_{16}$ as measurement errors. Furthermore, the latent endogenous variables are $\lambda_{y 1}$ to $\lambda_{y 12}$ (TRU1 to 3, FLOW1 to 3 , SAT1 to 3 , and INT1 to 3 ) as the constant of endogenous variables, $\eta_{1}$ to $\eta_{4}$ (Trust, Flow, Satisfaction, and Continued intentions toward mobile purchase) as the latent exogenous variables, and $\varepsilon_{1}$ to $\varepsilon_{12}$ as the 
measurement errors. Table 1 and Table 2 are summarized the information of the latent exogenous and endogenous variables.

Table 1. Mathematical equations of latent exogenous variables

\begin{tabular}{|c|c|c|c|c|}
\hline \multirow{2}{*}{ No } & \multicolumn{4}{|c|}{ Latent Exogenous Variable } \\
\hline & System Quality $\left(\xi_{1}\right)$ & Information Quality $\left(\xi_{2}\right)$ & Service Quality $\left(\xi_{3}\right)$ & Privacy and Security Concerns $\left(\xi_{4}\right)$ \\
\hline 1. & $S Y S 1=\lambda_{x 1} \xi_{1}+\delta_{1}$ & $I N F 1=\lambda_{x 6} \xi_{2}+\delta_{6}$ & $S E R 1=\lambda_{x 10} \xi_{3}+\delta_{10}$ & $P S C 1=\lambda_{x 14} \xi_{4}+\delta_{14}$ \\
\hline 2. & $S Y S 2=\lambda_{x 2} \xi_{1}+\delta_{2}$ & $I N F 2=\lambda_{x 7} \xi_{2}+\delta_{7}$ & $S E R 2=\lambda_{x 11} \xi_{3}+\delta_{11}$ & $P S C 2=\lambda_{x 15} \xi_{4}+\delta_{15}$ \\
\hline 3. & $S Y S 3=\lambda_{x 3} \xi_{1}+\delta_{3}$ & $I N F 3=\lambda_{x 8} \xi_{2}+\delta_{8}$ & $S E R 3=\lambda_{x 12} \xi_{3}+\delta_{12}$ & $P S C 3=\lambda_{x 16} \xi_{4}+\delta_{16}$ \\
\hline 4. & $S Y S 4=\lambda_{x 4} \xi_{1}+\delta_{4}$ & $I N F 4=\lambda_{x 9} \xi_{2}+\delta_{9}$ & $S E R 4=\lambda_{x 13} \xi_{3}+\delta_{13}$ & \\
\hline & $S Y S 5=\lambda_{x 5} \xi_{1}+\delta_{5}$ & & & \\
\hline
\end{tabular}

Table 2. Mathematical equations of latent endogenous variables

\begin{tabular}{|c|c|c|c|c|}
\hline \multirow{2}{*}{ No } & \multicolumn{4}{|c|}{ Latent Endogenous Variable } \\
\hline & Trust $\left(\eta_{1}\right)$ & Flow $\left(\eta_{2}\right)$ & Satisfaction $\left(\eta_{3}\right)$ & Continuance Intention $\left(\eta_{4}\right)$ \\
\hline 1. & $T R U 1=\lambda_{y 1} \eta_{1}+\varepsilon_{1}$ & $F L O W 1=\lambda_{y 4} \eta_{2}+\varepsilon_{4}$ & $S A T 1=\lambda_{y 7} \eta_{3}+\varepsilon_{7}$ & $I N T 1=\lambda_{y 10} \eta_{4}+\varepsilon_{10}$ \\
\hline 2. & $T R U 2=\lambda_{y 2} \eta_{1}+\varepsilon_{2}$ & $F L O W 2=\lambda_{y 5} \eta_{2}+\varepsilon_{5}$ & $S A T 2=\lambda_{y 8} \eta_{3}+\varepsilon_{8}$ & $I N T 2=\lambda_{y 11} \eta_{4}+\varepsilon_{11}$ \\
\hline 3. & $T R U 3=\lambda_{y 3} \eta_{1}+\varepsilon_{3}$ & $F L O W 3=\lambda_{y 6} \eta_{2}+\varepsilon_{6}$ & $S A T 3=\lambda_{y 9} \eta_{3}+\varepsilon_{9}$ & $I N T 3=\lambda_{y 12} \eta_{4}+\varepsilon_{12}$ \\
\hline
\end{tabular}

\subsection{Model Implementation}

The next step is the implementation of the SEM model. We developed the questionnaire based on the hypotheses proposed in the research model [12], as shown in Table 3. The questionnaire explained 17 declarations based on nine hypotheses, which consist of four latent exogenous and four latent endogenous variables (see Fig. 1). In these Hypotheses (H1 to H9), H6 to H9 were broken down into three declarations $(a, b$, and $c)$.

Table 3. The hypotheses and declarations

\begin{tabular}{ll}
\hline \multicolumn{1}{c}{ Hipotesis } & \multicolumn{1}{c}{ Declaration } \\
\hline H1 & Trust has a significant effect on continued intention towards mobile purchases \\
H2 & Flow has a significant effect on continued intention towards mobile purchase \\
H3 & Satisfaction has a significant effect on continued intention towards mobile purchase \\
H4 & Trust has a significant effect on flow \\
H5 & Trust has a significant effect on satisfaction \\
H6a & System quality has a significant effect on trust \\
H6b & System quality has a significant effect on flow \\
H6c & System quality has a significant effect on satisfaction \\
H7a & Information quality has a significant effect on terhadap trust \\
H7b & Information quality has a significant effect on flow \\
H7c & Information quality has a significant effect on satisfaction \\
H8a & Service quality has a significant effect on trust
\end{tabular}




\begin{tabular}{ll}
\hline \multicolumn{1}{c}{ Hipotesis } & \multicolumn{1}{c}{ Declaration } \\
\hline H8b & Service quality has a significant effect on flow \\
H8c & Service quality has a significant effect on satisfaction \\
H9a & Privacy and security that negatively has a significant effect on trust \\
H9b & Privacy and security that negatively has a significant effect on (concern negatively affects) flow \\
H9c & Privacy and security that negatively has a significant effect on satisfaction \\
\hline
\end{tabular}

Next, we develop the question points for the questionnaire of our study based on theexisting hypotheses, which are as follows.

1) System quality, the latent exogenous variables used to measure the system quality of MSA, which has five indicators (SYS1 to SYS5) for Hypothesis H6a to H6c.

2) Information quality, the latent exogenous variables used to measure the information quality of MSA, which has five indicators (INF1 to INF4) for Hypothesis H7a to H7c.

3) Service quality, the latent exogenous variable used to measure the service quality of MSA, which has five indicators (SER1 to SER4) for Hypothesis H8a to H8c.

4) Privacy and security concerns, the latent exogenous variables used to measure security and privacy related to data and transactions from the service quality of MSA, which has have three indicators (PSC1 to PSC3) for Hypothesis H9a to H9c.

5) Trust, the latent endogenous variable used to measure the user's level of trust in the provider of MSA, which has three indicators (TRU1 to TRU3) for Hypothesis H1 and H4.

6) Flow, the latent endogenous variable used to measure user experience in using MSA, which has three indicators (FLOW1 to FLOW3) for Hypothesis H2 and H5.

7) Satisfaction, the latent endogenous variable used to measure user satisfaction in using MSA, which has three indicators (SAT1 to SAT3) for Hypothesis H3.

8) Continued intention towards the mobile purchase, the latent endogenous variables used to measure how the user continued intention to online shopping using MSA, which has three indicators (INT1 to INT3).

\subsection{Survey}

The questions in the questionnaire used for the survey were arranged based on the indicators of each latent exogenous and latent endogenous variable. The aim of the questions are to test the established Hypotheses by Likert scale 1 to 7 - the questions designed to use MSA and user requirements in shopping online, as explained in Table 4. Respectively, as latent exogenous or latent endogenous variable in the SEM model, system quality, information quality, service quality, privacy and security concerns, trust, flow, satisfaction, and continuance intention have 5, 4, 4, 5, 3, 3, 3, and 3 questions. For instance, system quality (as the latent exogenous variable) has five questions. In our survey, each item is as loading factor of the latent exogenous and latent endogenous variable.

Table 4. The questionnaire questions

\begin{tabular}{lll}
\hline Variable & Indicator Code & \multicolumn{1}{c}{ Questionnaire Questions } \\
\hline & SYS1 & $\begin{array}{l}\text { In my opinion, the online shopping application displays images and writing quickly } \\
\text { (loading applications is quite fast). }\end{array}$ \\
$\begin{array}{l}\text { System quality } \\
\text { (Exogenous } \\
\text { variable) }\end{array}$ & SYS2 & In my opinion, the online shopping application is easy to use. \\
& SYS3 & In my opinion, the online shopping application has a display that is easy to operate. \\
& SYS5 & In my opinion, online shopping applications have attractive visual designs.
\end{tabular}




\begin{tabular}{|c|c|c|}
\hline Variable & Indicator Code & Questionnaire Questions \\
\hline \multirow{3}{*}{$\begin{array}{l}\text { Information } \\
\text { quality } \\
\text { (Exogenous } \\
\text { variable) }\end{array}$} & INF1 & $\begin{array}{l}\text { In my opinion, the information provided by the online shopping application is precise as } \\
\text { what I need. }\end{array}$ \\
\hline & INF2 & $\begin{array}{l}\text { In my opinion, the information provided by the online shopping application is easy to } \\
\text { understand. }\end{array}$ \\
\hline & INF3 & In my opinion, the information provided by the online shopping application is correct. \\
\hline \multirow{5}{*}{$\begin{array}{l}\text { Service quality } \\
\text { (Exogenous } \\
\text { variable) }\end{array}$} & INF4 & In my opinion, the information provided by the online shopping application is up-to-date. \\
\hline & SER1 & $\begin{array}{l}\text { In my opinion, online shopping applications provide timely services, e.g., estimated time } \\
\text { (delivery, processing of goods, refunding if the products are not processed) by the actual } \\
\text { conditions. }\end{array}$ \\
\hline & SER2 & In my opinion, customer service of online shopping applications is responsive. \\
\hline & SER3 & In my opinion, online shopping applications provide service which is functioning well. \\
\hline & SER4 & $\begin{array}{l}\text { In my opinion, online shopping applications also provide personalized services, e.g., there } \\
\text { are product recommendations that I often need. }\end{array}$ \\
\hline \multirow{3}{*}{$\begin{array}{l}\text { Privacy and } \\
\text { security concerns } \\
\text { (Exogenous } \\
\text { variable) }\end{array}$} & PSC1 & $\begin{array}{l}\text { I feel safe to share personal information with online shopping applications, e.g., name, } \\
\text { address, telephone number, parent's name, and others. }\end{array}$ \\
\hline & PSC2 & $\begin{array}{l}\text { I believe the personal information that I provided not traded without my permission, e.g., } \\
\text { name, address, telephone number, parent's name, and others. }\end{array}$ \\
\hline & PSC3 & $\begin{array}{l}\text { I feel safe doing financial transactions through online shopping applications, e.g., name, } \\
\text { address, telephone number, parent's name, and so on. }\end{array}$ \\
\hline \multirow{3}{*}{$\begin{array}{l}\text { Trust } \\
\text { (Endogenous } \\
\text { variable) }\end{array}$} & TRU1 & In my opinion, this online shopping application provider trusted. \\
\hline & TRU2 & $\begin{array}{l}\text { In my opinion, this online shopping application provider keeps its promises, e.g., claims } \\
\text { or offers given to users. }\end{array}$ \\
\hline & TRU3 & $\begin{array}{l}\text { In my opinion, this online shopping application provider always pays attention to customer } \\
\text { interests. }\end{array}$ \\
\hline \multirow{3}{*}{$\begin{array}{l}\text { Flow } \\
\text { (Endogenous } \\
\text { variable) }\end{array}$} & FLOW1 & My attention focused on purchasing activities when I do online shopping. \\
\hline & FLOW2 & $\begin{array}{l}\text { When purchasing the use of this application, all activities run as I expected, e.g., when } \\
\text { choosing an item, the event of putting it in shopping occurs after I agree. }\end{array}$ \\
\hline & FLOW3 & When purchasing use this application, I found many things that made me happy. \\
\hline \multirow{3}{*}{$\begin{array}{l}\text { Satisfaction } \\
\text { (Endogenous } \\
\text { variable) }\end{array}$} & SAT1 & $\begin{array}{l}\text { I feel satisfied with the services provided by this online shopping application, e.g., we buy } \\
\text { food (snacks, and so on), and we feel confident with the taste and the price cheap. }\end{array}$ \\
\hline & SAT2 & $\begin{array}{l}\text { I feel comfortable with the services provided by this online shopping application, e.g., the } \\
\text { appearance of the application is very suitable to my taste. }\end{array}$ \\
\hline & SAT3 & $\begin{array}{l}\text { I feel happy with the services provided by this online shopping application, e.g., this } \\
\text { application offers many discounts and other attractive promotions. }\end{array}$ \\
\hline \multirow{3}{*}{$\begin{array}{l}\text { Continuance } \\
\text { Intention } \\
\text { (Endogenous } \\
\text { variable) }\end{array}$} & INT1 & In the future, I want to use this application for online shopping. \\
\hline & INT2 & In the future, I prefer to shop online using this application than other applications. \\
\hline & INT3 & In the future, I will not do online shopping using this application. \\
\hline
\end{tabular}

In this study, we distribute an online questionnaire to the respondents (as customers) in the link https://bit.ly/surveiBO for two months (April-June 2019). The respondents who allowed to fill out it are customers who have made online purchases through MSA on Tokopedia, Shopee, and Bukalapak (customer experience). The respondents are limited to 15 to 34 years old (as $\mathrm{Y}$ and $\mathrm{Z}$ generation). We informed the questionnaire through in many ways, i.e., private message, social media groups, sharing information through 
sharing instantly and direct message on Instagram, providing information through Facebook and Twitter, and asking friends on campuses to help repost to other friends.

\subsection{Testing}

Before surveying using the designed questionnaire, we carried out pre-processing data to test the validity and reliability of the questionnaire against 50 randomly determined respondents [19]. The validity test is calculating the correlation coefficient ( $r$ ), while the reliability test carried out Cronbach's Alpha method [20]. The results of these tests state the questionnaire data is valid (all $r$-value of the indicator $>0.279$ ) and reliable $($ Cronbach's Alpha $=0.915>0.6)$. After declared valid and reliable, the questionnaire used to find data through surveys to MSA users who shop online. The testing result, we explain in the next section.

\section{Result and Discussion}

The results of this survey through these questionnaires have positive response according to the criteria of the expected respondents. We success get 509 respondents that summarized as follows.

1) The respondents who were by the criteria were $98.8 \%$ (400 respondents).

2) The respondents consist of 312 females (78\%) and 88 males (22\%).

3) The respondents who gave responses came from 20 of 34 provinces. The highest number of respondents is East Java (20.75\%), Central Java (14.25\%), West Java, and DKI Jakarta (21.50\%).

4) The percentage of respondent's age divided into four groups; 15-19 years (24\%), 20-24 years (54\%), 25-29 (17\%) Years, and 30-34 years (5\%).

5) The last time respondents did online shopping before filling out the questionnaire as follows; less than 1 month as many as 266 people (66.5\%), 1-3 months as many as 104 people (26\%), $4-6$ months as many as 16 people (14\%), and more than 6 months as many as 14 people $(3.5 \%)$.

6) The MSA used by respondents is as follows; Tokopedia 35\%, Shopee 47\%, and Bukalapak $18 \%$.

From the data obtained in the survey, we test the classical assumption to find out the normality of data [21, 22, 23] and present as follows. First, the Normality test with Skewness and Kurtosis shows that exogenous and endogenous variables normally distributed (all Skewness and Kurtosis values $> \pm 3$ and \pm 8 ). Second, Multivariate testing by identifying Mahalanobis values and Chi-Square shows the data is the normal distributed with correlation values higher than r-table (The scatter plot diagram shows almost a straight line).

After testing the data, we identify the factors that influence the continuing intention of online purchasing using MSA for the X and Y generation in Indonesia by confirmatory factor analysis (validity and reliability testing), as shown in Table 5. But, there are invalid indicators because it below the minimum value, namely SYS2, SYS5, SER4, and INT3. For this reason, these invalid indicators not used for testing the suitability of the model.

Table 5. Confirmatory factor analysis.

\begin{tabular}{llllllll}
\hline Indicator & $\begin{array}{c}\text { Loading } \\
\text { Factor }\end{array}$ & $\begin{array}{c}\text { Minimum } \\
\text { Value }\end{array}$ & Decision & Indicator & $\begin{array}{c}\text { Loading } \\
\text { Factor }\end{array}$ & $\begin{array}{c}\text { Minimum } \\
\text { Value }\end{array}$ & Decision \\
\hline SYS1 & 0.61 & 0,5 & Valid & PSC2 & 1,25 & 0,5 & Valid \\
SYS2 & 0.48 & 0,5 & Not Valid & PSC3 & 0,70 & 0,5 & Valid \\
SYS3 & 0.57 & 0,5 & Valid & TRU1 & 0,68 & 0,5 & Valid \\
SYS4 & 0.51 & 0,5 & Valid & TRU2 & 0,70 & 0,5 & Valid \\
SYS5 & 0.37 & 0,5 & Not Valid & TRU3 & 0,52 & 0,5 & Valid \\
INF1 & 0.67 & 0,5 & Valid & FLOW1 & 0,56 & 0,5 & Valid
\end{tabular}


Mudjahidin et al. / Jurnal SISFO Vol.09 No.01 (2019) 29-40

\begin{tabular}{llllllll}
\hline \multicolumn{1}{c}{ Indicator } & $\begin{array}{c}\text { Loading } \\
\text { Factor }\end{array}$ & $\begin{array}{c}\text { Minimum } \\
\text { Value }\end{array}$ & \multicolumn{1}{c}{ Decision } & Indicator & $\begin{array}{c}\text { Loading } \\
\text { Factor }\end{array}$ & $\begin{array}{c}\text { Minimum } \\
\text { Value }\end{array}$ & Decision \\
\hline INF2 & 0.60 & 0,5 & Valid & FLOW2 & 0,64 & 0,5 & Valid \\
INF3 & 0.77 & 0,5 & Valid & FLOW3 & 0,66 & 0,5 & Valid \\
INF4 & 0.66 & 0.5 & Valid & SAT1 & 0.63 & 0.5 & Valid \\
SER1 & 0.51 & 0.5 & Valid & SAT2 & 0.66 & 0.5 & Valid \\
SER2 & 0.56 & 0.5 & Valid & SAT3 & 0.67 & 0.5 & Valid \\
SER3 & 0.67 & 0.5 & Valid & INT1 & 0.67 & 0.5 & Valid \\
SER4 & 0.49 & 0.5 & Not Valid & INT2 & 0.55 & 0.5 & Valid \\
PSC1 & 1,15 & 0.5 & Valid & INT3 & 0.31 & 0.5 & Not Valid \\
\hline
\end{tabular}

Table 6. Instrument reliability test

\begin{tabular}{|c|c|c|c|c|c|c|}
\hline Var. & Indicator & Std. & Error Var. & $\mathrm{CR}(\geq 0.6)$ & $\operatorname{AVE}(\geq 0.4)$ & Description \\
\hline \multirow{3}{*}{ SYS } & SYS1 & 0.55 & 0.69 & \multirow{3}{*}{0.609} & \multirow{3}{*}{0.342} & \multirow{3}{*}{ Not reliable } \\
\hline & SYS3 & 0.68 & 0.54 & & & \\
\hline & SYS4 & 0.51 & 0.74 & & & \\
\hline \multirow{4}{*}{ INF } & INF1 & 0.72 & 0.49 & \multirow{4}{*}{0.797} & \multirow{4}{*}{0.497} & \multirow{4}{*}{ Reliable } \\
\hline & INF2 & 0.68 & 0.54 & & & \\
\hline & INF3 & 0.77 & 0.41 & & & \\
\hline & INF4 & 0.65 & 0.58 & & & \\
\hline \multirow{3}{*}{ SER } & SER1 & 0.51 & 0.74 & \multirow{3}{*}{0.634} & \multirow{3}{*}{0.375} & \multirow{3}{*}{ Not reliable } \\
\hline & SER2 & 0.52 & 0.73 & & & \\
\hline & SER3 & 0.77 & 0.4 & & & \\
\hline \multirow{3}{*}{ PSC } & PSC1 & 0.79 & 0.37 & \multirow{3}{*}{0.796} & \multirow{3}{*}{0.568} & \multirow{3}{*}{ Reliable } \\
\hline & PSC2 & 0.81 & 0.35 & & & \\
\hline & PSC3 & 0.65 & 0.57 & & & \\
\hline \multirow{3}{*}{ TRU } & TRU1 & 0.72 & 0.49 & \multirow{3}{*}{0.722} & \multirow{3}{*}{0.467} & \multirow{3}{*}{ Reliable } \\
\hline & TRU2 & 0.75 & 0.43 & & & \\
\hline & TRU3 & 0.57 & 0.68 & & & \\
\hline \multirow{3}{*}{ FLOW } & FLOW1 & 0.43 & 0.82 & \multirow{3}{*}{0.636} & \multirow{3}{*}{0.378} & \multirow{3}{*}{ Not Reliable } \\
\hline & FLOW2 & 0.66 & 0.56 & & & \\
\hline & FLOW3 & 0.72 & 0.49 & & & \\
\hline \multirow{3}{*}{ SAT } & SAT1 & 0.75 & 0.44 & \multirow{3}{*}{0.817} & \multirow{3}{*}{0.599} & \multirow{3}{*}{ Reliable } \\
\hline & SAT2 & 0.79 & 0.38 & & & \\
\hline & SAT3 & 0.79 & 0.39 & & & \\
\hline \multirow{2}{*}{ INT } & INT1 & 0.91 & 0.18 & \multirow{2}{*}{0.640} & \multirow{2}{*}{0.562} & \multirow{2}{*}{ Reliable } \\
\hline & INT2 & 0.55 & 0.7 & & & \\
\hline
\end{tabular}


In addition to the validity and reliability testing, we conduct the instrument reliability test to ensure the variables are reliable or consistent by calculating construct reliability $(\mathrm{CR})$ and average variance extracted (AVE), as shown in Table 6.

The results of the instrument reliability test above indicates that all variables have CR $>0.6$, and three variables (SYS, SER, and FLOW) have AVE $\leq 0.4$. However, this study focused on CR to determine the level of variable reliability. Therefore, although three variables have AVE $\leq 0.4$, these variables still considered reliable because CR is sufficient.

Besides, we do the test of model suitability to determine the level of model relevance (called ad The Good Fit Model Test). Model suitability tests based on seven indexes, namely Cmin/df, GFI, AGFI, NFI, TLI/NNFI, CFI, and RMSEA, as shown in Table 7.

Table 7. Good Fit Models Test

\begin{tabular}{llll}
\hline Suitability test index & \multicolumn{1}{c}{ Result } & \multicolumn{1}{c}{ Cut Off Value } & Description \\
\hline Cmin/df. & $\begin{array}{l}1.938 \\
(\text { Cmin }=439,97 \text { and } \mathrm{df}=227)\end{array}$ & Good fit $(\leq 2)$ & Good Fit \\
GFI & 0.92 & Good fit $(\geq 0.9)$ & Good Fit \\
AGFI & 0.89 & Good fit $(\geq 0.9)$ & Marginal Fit \\
NFI & 0.95 & Marginal fit $(0,8 \leq$ AGFI $\geq 0.9)$ & \\
TLI/NNFI & 0.97 & Good fit $(\geq 0.9)$ & Good Fit \\
CFI & 0.98 & Good fit $(\geq 0.9)$ & Good Fit \\
RSMEA & 0.048 & Good fit $(\geq 0.9)$ & Good Fit \\
\hline
\end{tabular}

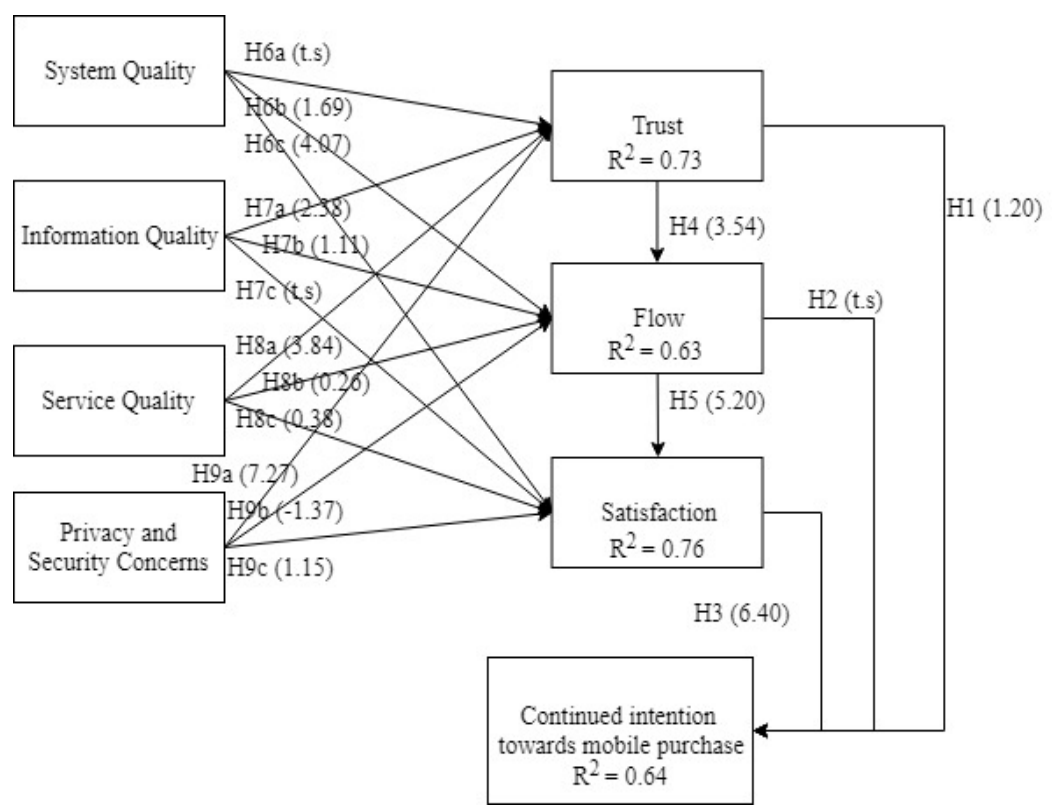

Figure 2. SEM model as the result with hypothesis value between variables 
We summarize the result of the study as follows. For endogenous variables, the results indicate that satisfaction significantly affects continued intention towards the mobile purchase (the greatest among others =6.4). Besides, trust has a positive value but not significantly affect the continued intention towards the mobile purchase (1.2), while flow has a negative effect on continued intention. On the other hand, exogenous variables that affect endogenous variables (trust, flow, and satisfaction) are service quality, whereas information quality has a positive effect on trust and flow. System quality has a positive impact on flow and satisfaction, while privacy and security concerns have a positive effect on trust and satisfaction. In sum, Fig. 2 illustrates the relationship between all variables and the corresponding hypothesis values.

Based on the results of this study, we know that system quality has a positive effect on flow $(\beta=0.19)$, and satisfaction $(\beta=0.38)$. The quality of system attracts users in conducting online shopping transactions. It because user experience in the application is needed by the user to understand and use the application features, as explained by Moursalien [24]. Therefore, satisfaction can be achieved by improving the quality of the system that is easy to use by the customer. Information quality has a positive effect on trust $(\beta=0.19)$ and flow $(\beta=0.12)$. Thus, user trust can be improved by always providing the latest and reliable information so that users can find the information needed. For instance, information on the implementation of the service fee scheme must clear, along with what features can be accessed [25]. Moreover, service quality has a positive effect on all variables trust $(\beta=0.32)$, flow $(\beta=0.029)$, and satisfaction $(\beta=$ 0.030).

To increase customer's trust, ease of application access, and satisfaction, application providers must pay attention to the quality of services provided to customers. Innovations and new ideas must be developed to be able to deliver excellent service quality [26]. Having a shared discount day campaign can grow ecommerce transactions [27]. However, the most important thing is to maintain and improve the quality provided to users [28]. Privacy and security concerns positively affect trust $(\beta=0.56)$ and satisfaction $(\beta=0.080)$. Users believe that each personal data is managed properly by the application provider [29], and legal regulations must be carried out transparently when related to data security and privacy [30]. So that when users feel confident with the application, it possible that users are satisfied with the MSA.

The relationship between trust and flow $(\beta=0.72)$ has a positive and significant effect - these results following Gao et al. [12]. When the user's trust in MSA is getting higher, the users will become more familiar with the flow of MSA so that online shopping experience becomes more convenient and comfortable. The relationship between flow and satisfaction $(\beta=0.61)$ has a positive and significant effect. This result consistent with the study by Gao et al. [12]. When users have a pleasant shopping experience using MAS, users can feel satisfied with the MAS. This condition will make users more comfortable and enjoy online shopping.

The results obtained in this study indicate that satisfaction $(\beta=0.74)$ has a significant effect on continued intention towards mobile purchase. Besides, satisfaction positively affected by system quality, whereas system quality also has positive effect to trust and satisfaction. Customer satisfaction can be seen from the service quality provided by MSA providers (Tokopedia, Shopee and Bukalapak). Currently, MSA provider of MAS must focus on the quality of services offered to customers, because e-commerce not only focuses on selling their products but the quality of services provided [28]. For this reason, MSA providers need to pay attention to customer satisfaction because satisfaction has a significant influence on customer sustainability intentions in making purchases online using MSA. Therefore, to support the creation of excellent customer satisfaction, MSA providers must improve and renew their innovation and creativity both in terms of applications and services provided to consumers so that this can attract users to continue to use MSA to shop online.

Other variables that can be added for further study are frequent usage, subjective norm, and control variables (gender, age, and income). As a reason, the variable of continual usage can have a significant impact as a 
driver for someone to shop online. The frequent usage requires a small effort, makes simple decisions, processes information quickly, and helps a person's performance become more efficient [31]. The habit of consumers can shape sustainability behavior in online shopping [28]. Sometimes, in online shopping, norms variables could include the attention of other personal opinions. So that the assessment of other variables can be one of the essential and significant things to determine online shopping decisions, and control variables (gender, age, and income), due to age conditions can affect their shopping intentions. At a young age, the experience of online and internet shopping are quite familiar. Gender can also be one of the different and exciting shopping habits in the marketing department [26, 27, 28, 31].

\section{Conclusion}

In this study, we have succeeded in the analysis of purchase intention using the MSA for X and Y Generation in Indonesia. We found that continued intention towards a purchase (as of end variable in the research model by Gao et al.) in online shopping is significantly affected by satisfaction, flow, and trust (respectively, $\beta=$ $0.74,0.72$, and 0.72 ). Satisfaction is related to customer satisfaction in using MSA to meet their online shopping needs. The customers will satisfy if the quality of service of MSA continues to maintain and improve. The customers will be satisfied if the service quality of MSA continues to maintain and improve. Services quality provided might be balanced, so the customers feel satisfied doing online shopping using MSA.

Based on the literature review studied, several variables can be added to complement the research model so that the results obtained will be more thorough. Moreover, variables that can be added to the model are frequent usage, subjective norm, and control variables (i.e. gender, age, and income).

\section{References}

[1] A. H. Pratama, "Mengapa bos Traveloka menyarankan para startup untuk membuat aplikasi mobile?" Available: https://id.techinasia.com/alasan-membuat-aplikasi-mobile. [Accessed 103 2019].

[2] H. Edison N. M. Smørsgård, X. Wang, P. Abrahamsson, "Lean internal startups for software product innovation in large companies: enablers and inhibitors," Journal of Systems and Software, vol. 135, pp. 69-87, 2018.

[3] F. F. Reichheld, P. Schefter, "E-loyalty: your secret weapon on the web," Available: https://hbr.org/2000/07/e-loyalty-your-secretweapon-on-the-web. [Accessed 103 2019].

[4] S. Pahnila and J. Warsta, "Online shopping viewed from a habit and value perspective," Behaviour \& Information Technology, vol. 29 , pp. 37-41, 2010 .

[5] M A. A. Dew, A. N. Hidayanto, M. R. Shihab, and Y. -Q. Zhu, "Trust transfer and its effects on the continuance usage of mobile service in B2C e-marketplaces," in PACIS2017, Langkawi Island, Malaysia, 2017.

[6] E. W. T. Ngaiand and A. Gunasekaran, "A review for mobile commerce research and applications" Decision Support Systems, vol. 43, pp. 3-15, 2007.

[7] F. Chu and X. Zhang, "Satisfaction, trust and online purchase intention: A study of consumer perceptions," Sydney, NSW, Australia, 2016.

[8] Google, "Google Play Store," 2016. Available: https://play.google.com/store. [Accessed 152 2019].

[9] R. Anderson and S. Srinivasan, "E-satisfaction and E-loyalti: a continegcy framework," Journal of Psychology and Marketing, vol. 20, no. 2, pp. 123-138., 2003.

[10]W. Delone and E. McLean, "The DeLone and McLean model of information systems success: A ten-year update," Journal of Management Information Systems, vol. 19, no. 4, pp. 9-30, 2003.

[11]A. W. Utami, “Analisa kesuksesan sistem informasi akademik (SIAKAD) di perguruan tinggi dengan menggunakan pendekatan D \& MIS success model,” Institut Teknologi Sepuluh Nopember (ITS)-Surabaya, 2013.

[12]L. Gao, K. A. Waechter; and X. Bai, "Computers in Human Behavior Understanding consumers continuance intention towards mobile purchase : A theoretical framework and empirical study - A case of China," Computers in Human Behavior, vol. 53, p. pp. 249-262., 2015.

[13]N. Kassim and N. A. Abdullah, "The effect of perceived service quality dimensions on customer satisfaction , trust , and loyalty in e-commerce settings: A cross cultural analysis," Marketing and Logistics cultural analysis, vol. 22, no. 3, pp. 351-371, 2010.

[14]R. Rohwiyati; P. Praptiestrini, "The effect of shopee e-service quality and price perception on repurchase intention: Customer satisfaction as mediation variable," Indonesian Journal of Contemporary Management Research, vol. 1, no. 1, pp. 47-54, 2019.

[15]Bukalapak, "Panduan Belanja Online di Bukalapak," Available: https://panduan.bukalapak.com/buyer. [Accessed 42 2019].

[16] Tokopedia, "Cara Berbelanja di Tokopedia," 2019. Available: https://www.tokopedia.com/bantuan/pembeli/belanja-ditokopedia/\#cara-berbelanja-di-tokopedia. [Accessed 42 2019]. 
[17]W. T. Lai and C. -F. Chen, "Behavioral intentions of public transit passengers-The roles of service quality, perceived value, satisfaction and involvement," Transport Policy, vol. 18, no. 2, pp. 318-325, 2011.

[18]R. Wahyuni, "Analisis pengaruh service quality, perceived value, satisfaction, dan involvement terhadap behavioral intentions penumpang (Studi kasus: Transjakarta Busway)," Fakultas Ekonomi-Universitas Indonesia, 2012.

[19] J. Sarwono, Buku pintar IBM statistics. Jakarta: PT. Elex Media Komputindo, 2011.

[20]M. Kuncoro, Metode riset untuk bisnis dan ekonomi. Jakarta: Erlangga, 2003.

[21]S. Haryadi and J. Winda, Structural equation modelling (SEM): Sebuah pengantar, aplikasi untuk penelitian bisnis. Jakarta: Salemba Empat, 2015.

[22] O.- M. Kwok, M. W. L. Cheung, S. Jak, E. Ryu, and J. -Y. Wu, "Recent advancements in structural equation modeling (SEM): From both methodological and application perspectives," Frontiers in Phsycology, vol. 9, pp. 1-3, 2018.

[23] J. F. Hair, Multivariate data analysis. Edinburg: Pearson Education Limited, 2014.

[24]F. Moursalien, "10 tren e-commerce di Asia Tenggara tahun 2015," Available: https://id.techinasia.com/tren-ecommerce-asiatenggara-2015. [Accessed 52 2019].

[25]R. Maulana, "Tokopedia ubah skema biaya layanan power merchant Jadi berdasarkan Transaksi," Available: https://id.techinasia.com/tokopedia-model-pendapatan-power-merchant?ref=popular\&cat=2\&pos=3 . [Accessed 162019 ].

[26]H. Pratama, " 3 Hal Penting dalam Melakukan Growth Hack menurut COO Bukalapak Willix Halim, TechinAsia," Available: https://id.techinasia.com/3-tip-growth-hack-dari-coo-bukalapak-willix-halim. [Accessed 17 2019].

[27]H. Pratama, "Kilas balik perkembangan e-commerce di Indonesia sepanjang tahun 2016," Available: https://id.techinasia.com/kilas-balik-perkembangan-e-commerce-di-tahun-2016. [Accessed 17 2019].

[28]P. A. Satrianti , "Bagaimana Humas Bisa Berperan dalam Memaksimalkan Bisnis E-Commerce, TechinAsia," 2017. [Online]. Available: https://id.techinasia.com/bagaimana-humas-ikut-berperan-memaksimalkan-bisnis-e-commerce. [Accessed 272019 ].

[29] TechInAsiaID, "Rangkuman berita startup dan teknologi Indonesia dalam sepekan," Available: https://id.techinasia.com/rangkuman-berita-startup-29-juni-2019?ref=popular\&cat=1\&pos=4. [Accessed 172019 ].

[30] G. Olsen, S. G. Chua, O. Gergela, andF. Bartolucci, "Lifting the barriers to e-commerce in ASEAN," Korea: AT Kaerney, 2011.

[31]H. Aarts, B. Verplanken, and A. v. Knippenberg, "Predicting behavior from actions in the past: Repeated decision making or a matter of habit?," Journal of Applied Social Psychology, vol. 28, no. 15, pp. 1355-1374, 1998. 
